\title{
GEOPHYSICAL INVESTIGATION OF GROUNDWATER POTENTIAL OF A SITE IN OBALE AREA OF AKURE, NIGERIA.
}

\author{
Eebo Festus Olusola. \\ Federal University of Technology, Akure, \\ Nigeria
}

Abstract - Electrical Resistivity method using Vertical Electrical Soundings (VES) were carried out at a site in Aba-Oyo area FUTA Southgate area, Akure, Nigeria, with the aim to access groundwater potential of the site. The study area is underlain by crystalline rocks of the Precambrian basement complex of the Southwestern Nigeria. Twelve (12) VES were carried out using Schlumberger electrode array configuration with $A B / 2$ from 1 to $65 \mathrm{~m}$. The VES data generated were processed and interpreted using partial curve matching method and computer iteration techniques. The interpreted data revealed three to four geoelectric sections with varied thicknesses and resistivity. The top soil layer ranges from 44 to $181 \Omega \mathrm{m}$, lateritic clay layer ranges from 20 to $174 \Omega \mathrm{m}$, the weathered horizon resistivity ranges from 20.0 to $424.0 \Omega \mathrm{m}$ while the competent rock/fresh rock has resistivity values greater than $424.0 .3 \Omega \mathrm{m}$. The top soil layer resistivity and thickness ranges from 44 to $181 \Omega$ m and 0.4 to $2 \mathrm{~m}$, the lateritic clay layer resistivity and thickness range from 20 to $174 \Omega \mathrm{m}$ and 1.7 to $6.0 \mathrm{~m}$ respectively, the weathered horizon resistivity ranges from 20.0 to $424.0 \Omega \mathrm{m}$ and 1.4 to $7.4 \mathrm{~m}$ respectively while the competent rock has resistivity values greater than $424.0 \Omega m$ and $\infty \mathrm{m}$ respectively. The third geoelectric layer constitutes the aquiferous zone in the 4-layer geoelectric section while the second geoelectric layer is the aquiferous zone in all the 3- layer geoelectric sections. VES station 2, 7, 9 stations shows good groundwater potential as revealed by the thick overburden and weathered layer with low resistivity values. VES stations $1,4,5,6,8,10$ and 12 shows moderate groundwater potentials while VES stations 3 and 11 are non-aquifereous in nature.

Key words: Geoelectric, investigation, underground water, lithology, columnar section

\author{
Yusuf Gbenga Ayodele \\ Federal University of Technology, Akure, \\ Nigeria
}

I. INTRODUCTION

Groundwater conditions at a location are mainly described through the distribution of permeable layers (like sand, gravel, fractured rock) and impermeable or low-permeable layers (like clay, till, solid rock) in the subsurface.

Groundwater has become immensely important for different water supply purposes in urban and rural areas of both the developed and developing countries. However, groundwater exploration in hard rock terrain is a very challenging and difficult task, if the promising groundwater zones are associated with fractured and fissured media. In such an environment, the groundwater potentiality depends mainly on the thickness of the weathered/ fractured layer overlying the basement. Most groundwater projects recorded in basement complex aquifers have revealed geophysical survey as a compulsory perquisite to any successful water well drilling project [7]. The electrical resistivity method involving the vertical electrical sounding, (VES) technique is extensively gaining application in environmental, groundwater and engineering geophysical investigations [4],[1[3],[8],[5], [6], [9].

The electrical resistivity method involving the vertical electrical sounding, (VES) technique is extensively gaining application in basement.

\section{A. LOCATION AND ACCESSIBILITY OF} THE STUDY AREA

The study area is located at Aba-Oyo area FUTA Southgate area, Akure. It is accessible through FUTA road from South gate via the Stateline road. The area is bounded by Easting - $0737782 \mathrm{mE}$ and $0737740 \mathrm{mE}$ and Northing $0805958 \mathrm{mN}$ and $0805976 \mathrm{mN}$ in Universal Traverse Mercator (UTM) Minna Zone 31. The study area is geographically located within the sub-equatorial climate belt of tropical rain-forest vegetation with evergreen and broad-leaved trees luxuriant growth layer arrangement [2]. The area is characterized by uniformly high temperature and 


\section{International Journal of Engineering Applied Sciences and Technology, 2021 \\ Vol. 6, Issue 1, ISSN No. 2455-2143, Pages 88-93 \\ Published Online May 2021 in IJEAST (http://www.ijeast.com)}

heavy, well distributed rainfall throughout the year. The mean annual temperature is $24^{\circ} \mathrm{C}-27^{\circ} \mathrm{C}$, while the rainfall, mostly conventional, peaks twice in July and September and varies between $1500 \mathrm{~mm}$ and $3500 \mathrm{~mm}$ per year [2].

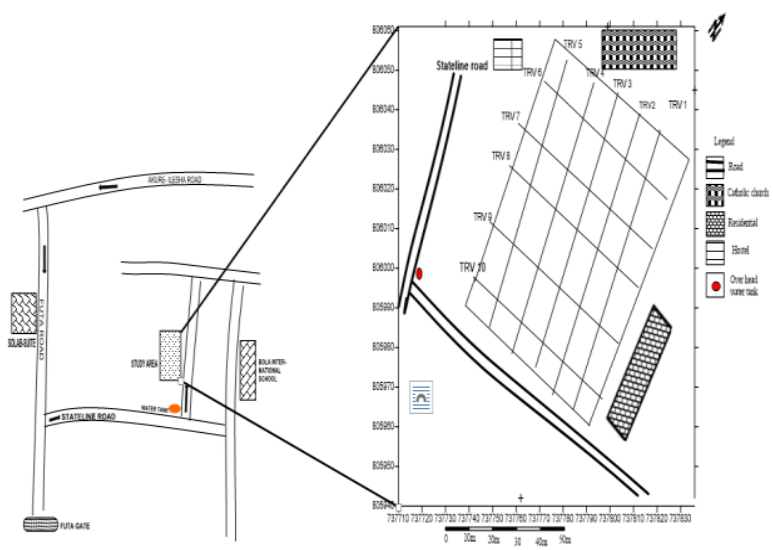

Figure 1.1 Directional Sketch to the Study Area and location map of the study area.

\section{GEOLOGY OF THE STUDY AREA}

The study area is underlain by crystalline rocks of the Precambrian basement complex of the Southwestern Nigeria [11], [2], [10]

The fractured bedrock generally occur in a typical basement terrain in tropical and equatorial regions, weathering processes create superficial layers, with varying degree of porosity and permeability studies have shown that the unconsolidated overburden could constitute reliable aquifer if significantly thick [7], [8].

The lithological units include Migmatic gneiss complex, granitic gneiss and Charnokites. Outcrops of biotite gneiss and

granitic gneiss occur in some locations around the western part of the study area. Likewise some other boulders of granite and charnokites occur at the western flank of the study area.

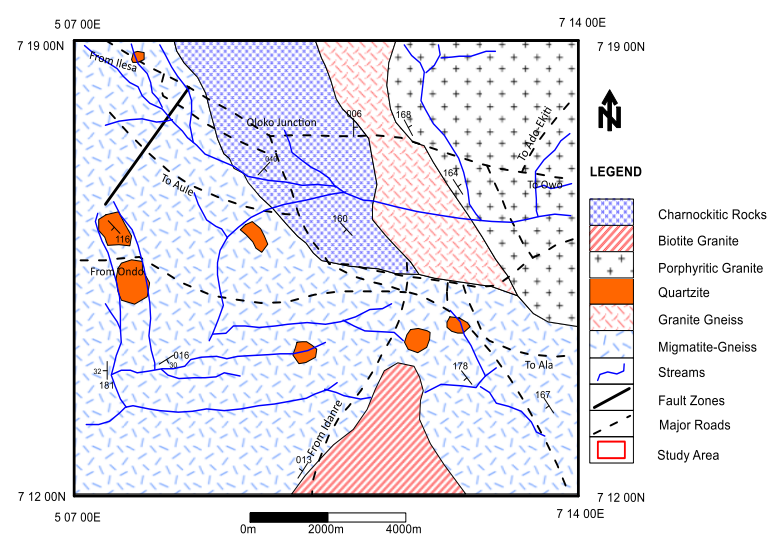

Figure 2.1 Simplified Geological Map of Akure (after Owoyemi 1996).

\section{METHODOLOGY}

Data acquisition utilizes geophysical techniques which is, Electrical resistivity method utilizing vertical electrical sounding, Ten traverses were established (5 running from South to North direction with maximum distance of about $75 \mathrm{~m}$ and 5 running from East to West with maximum distance of about $55 \mathrm{~m}$ ). Twelve vertical electrical sounding was conducted along the traverses. The current electrode $(\mathrm{AB} / 2)$ was varied from 1-65m because of the limited space of spreading.

Resistivity values were obtained by taking readings using Omega resistivity meter, four electrodes and connecting cables. Resistivity

readings taking using the Schlumberger array was undertaken by keeping the center of the array fixed and expanding the current electrodes separation, thus obtaining the resistivity readings with depth. DC current was injected into the earth through the current electrodes $\mathrm{C} 1$ and $\mathrm{C} 2$, while the resulting potential was measured across the potential electrodes $\mathrm{P} 1$ and $\mathrm{P} 2$.

The resulting potential difference to the current is displayed by the digital resistivity equipment as a resistance. The electrode spacing is progressively increased, keeping the center point of the electrode array fixed. At small electrode spacing, the apparent resistivity is nearly the resistivity of the surface material, but as the current electrodes spacing increase the current penetrates deeper within the subsurface and so the apparent resistivity reflects the resistivity of the deeper layers as well. The apparent resistivity values are obtained by multiplying the measured resistance with an appropriate geometric factor. Different factors affect the resistivity in the subsurface (Telford et al, 1990).

$\rho_{a=} K\left(\frac{\Delta V}{I}\right)$ 


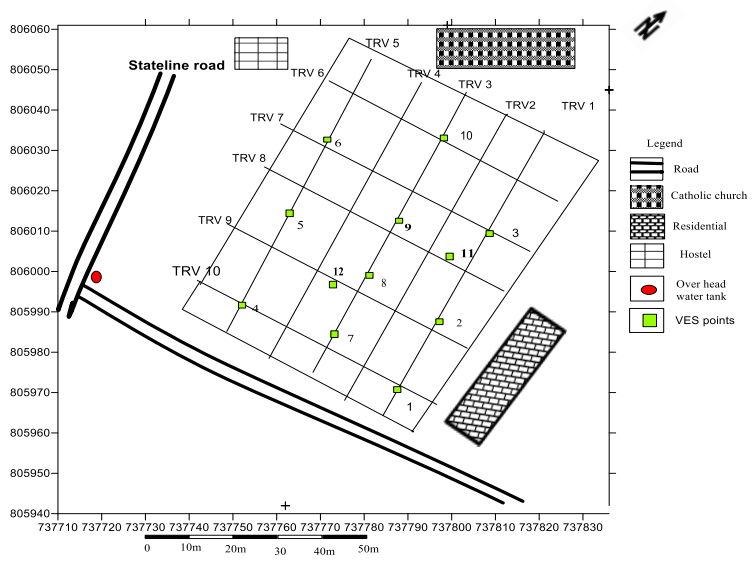

Figure 3.1 Data Acquisition Map.

\section{RESULTS AND DISCUSSIONS}

The apparent resistively values $\left(\boldsymbol{\rho}_{\boldsymbol{a}}\right)$ were plotted against the current electrodes separation $(A B / 2)$ on log-log graph papers, in order to generate initial values to use for the computation of analysis and interpretation with a computer iterated software known as RESIST. The results obtained from this study are presented as tables, depth sounding curves and pseudo sections.

\section{A. VERTICAL ELECTRICAL SOUNDING RESULTS}

A total of twelve (12) Vertical Electrical Sounding stations were occupied and the results of 12 VES points are presented as: sounding curves and columnar sections.

The 12 sounding curves were classified into three types: $\mathrm{KH}, \mathrm{H}$ and HA curves. Typical curve types are shown in Figures 4.1 to 4.6 while the summary of the results i.e. the geo - electric parameters obtained from the VES curves interpretation is presented in table 1.0 below

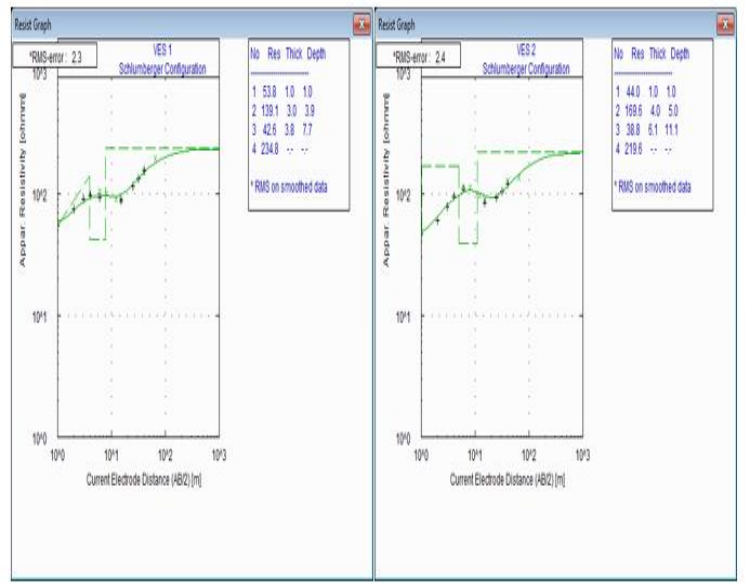

Figure 4.1:

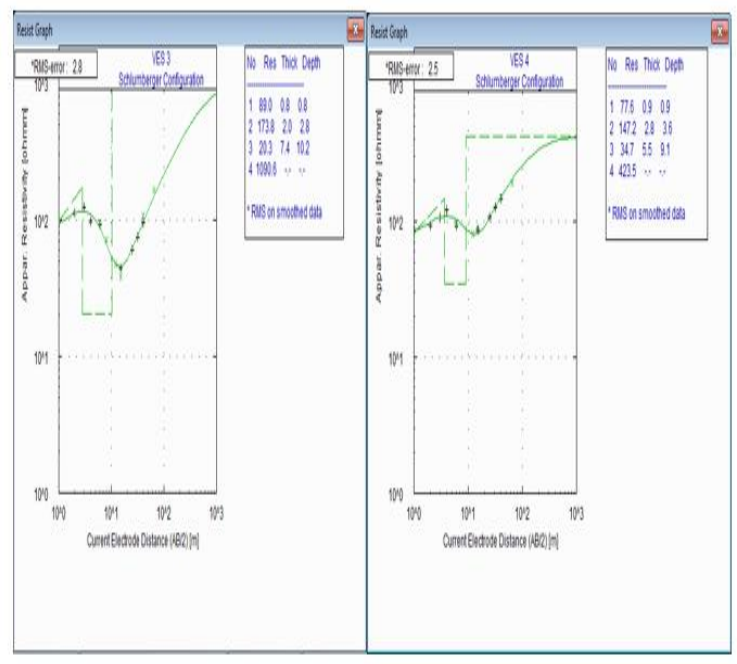

Figure 4.2:

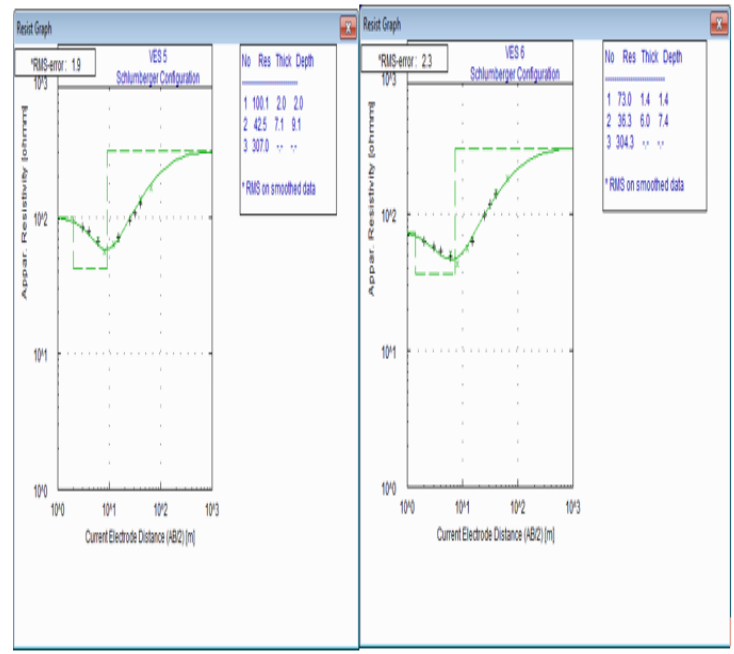

Figure 4.3:

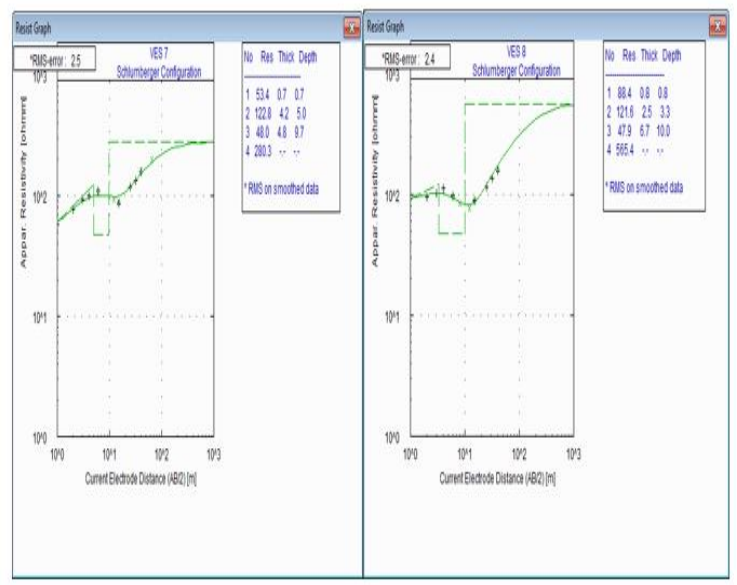

Figure 4.4: 

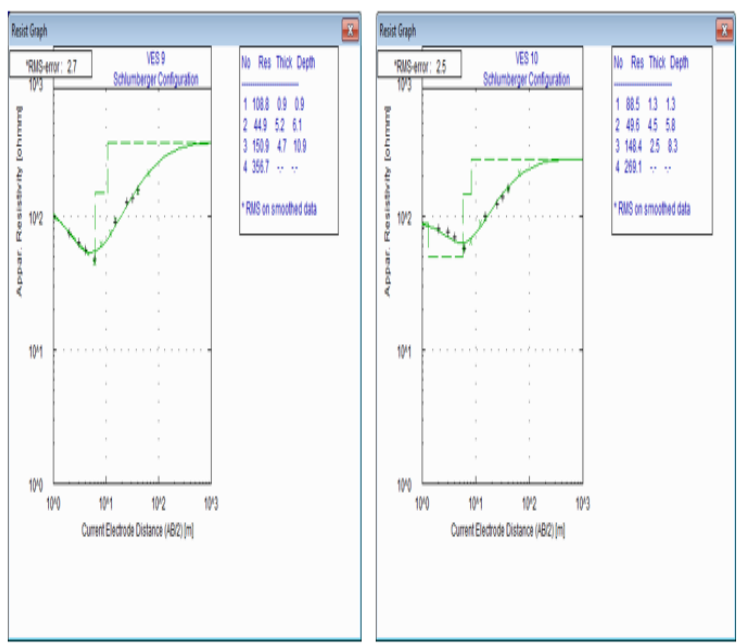
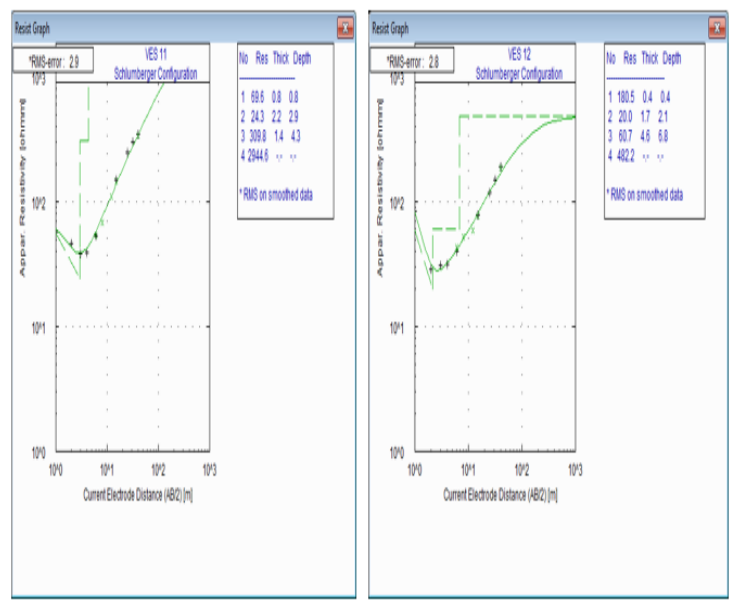

Figure 4.6:

Figure 4.5:

\begin{tabular}{|c|c|c|c|c|c|c|}
\hline $\begin{array}{l}\text { VES } \\
\text { Station }\end{array}$ & $\begin{array}{l}\text { NO. of } \\
\text { layers }\end{array}$ & $\begin{array}{l}\text { Resistivity } \\
(\text { Ohm-m) } \\
\rho_{1 / \rho_{2} / \ldots \rho_{n-1}}\end{array}$ & $\begin{array}{l}\text { Curve } \\
\text { Type }\end{array}$ & $\begin{array}{l}\text { Thickness(m) } \\
\mathbf{h}_{1} / \mathbf{h}_{2 /} \mathbf{h}_{3}\end{array}$ & $\begin{array}{l}\operatorname{Depth}(\mathbf{m}) \\
\mathbf{d}_{1} / \mathbf{d}_{2} / \ldots \mathrm{d}_{\mathrm{n}-1}\end{array}$ & Lithologies/ \\
\hline 1 & 4 & $54 / 139 / 43 / 235$ & $\mathrm{KH}$ & $1.0 / 2.9 / 3.8$ & $1.0 / 3.9 / 7.7$ & $\begin{array}{l}\text { Top soil / Lateritic layer / Highly } \\
\text { weathered or fractured layer / Weathered } \\
\text { layer }\end{array}$ \\
\hline 2 & 4 & $44 / 170 / 39 / 220$ & $\mathrm{KH}$ & $1.0 / 4.0 / 6.1$ & $1.0 / 5.0 / 11.1$ & $\begin{array}{l}\text { Top soil / Lateritic layer / Highly } \\
\text { weathered or fractured layer / Weathered } \\
\text { layer }\end{array}$ \\
\hline 3 & 4 & $89 / 174 / 20 / 1091$ & $\mathrm{KH}$ & $0.8 / 2.0 / 7.4$ & $0.8 / 2.8 / 10.2$ & $\begin{array}{l}\text { Top soil / Lateritic layer / Highly } \\
\text { weathered or fractured layer / fresh } \\
\text { basement. }\end{array}$ \\
\hline 4 & 4 & $78 / 147 / 35 / 424$ & $\mathrm{KH}$ & $0.9 / 2.8 / 5.5$ & $0.9 / 3.6 / 9.1$ & $\begin{array}{l}\text { Top soil / Lateritic layer / Highly } \\
\text { weathered or fractured layer / Weathered } \\
\text { layer }\end{array}$ \\
\hline 5 & 3 & $100 / 43 / 307$ & $\mathrm{H}$ & $2.0 / 7.1$ & $2.0 / 9.1$ & $\begin{array}{l}\text { Top soil / Clayey or Lateritic layer / } \\
\text { Highly weathered or fractured layer }\end{array}$ \\
\hline 6 & 3 & $73 / 36 / 304$ & $\mathrm{H}$ & $1.4 / 6.0$ & $1.4 / 7.4$ & $\begin{array}{l}\text { Top soil / Clayey or Lateritic layer / } \\
\text { Highly weathered or fractured layer }\end{array}$ \\
\hline 7 & 4 & $53 / 123 / 48 / 280$ & $\mathrm{KH}$ & $0.7 / 4.2 / 4.8$ & $0.7 / 5.0 / 9.7$ & $\begin{array}{l}\text { Top soil / Lateritic layer / Highly } \\
\text { weathered or fractured layer / Weathered } \\
\text { layer }\end{array}$ \\
\hline 8 & 4 & $89 / 122 / 48 / 565$ & $\mathrm{KH}$ & $0.8 / 2.5 / 6.7$ & $0.8 / 3.3 / 10.0$ & $\begin{array}{l}\text { Top soil / Lateritic layer / Highly } \\
\text { weathered or fractured layer / Weathered } \\
\text { layer }\end{array}$ \\
\hline 9 & 4 & $109 / 45 / 151 / 357$ & HA & $0.9 / 5.2 / 4.7$ & $0.9 / 6.1 / 10.9$ & $\begin{array}{l}\text { Top soil / Lateritic layer / Highly } \\
\text { weathered or fractured layer / Weathered } \\
\text { layer }\end{array}$ \\
\hline 10 & 4 & $89 / 50 / 148 / 269$ & HA & $1.3 / 4.5 / 2.5$ & $1.3 / 5.6 / 8.3$ & $\begin{array}{l}\text { Top soil / Clayey or Lateritic layer / } \\
\text { Highly weathered or fractured layer / } \\
\text { Weathered layer }\end{array}$ \\
\hline 11 & 4 & $70 / 24 / 310 / 2945$ & HA & $0.8 / 2.2 / 1.4$ & $0.8 / 2.9 / 4.3$ & $\begin{array}{l}\text { Top soil / clayey material / Weathered or } \\
\text { fractured layer / Fresh basement. }\end{array}$ \\
\hline 12 & 4 & $181 / 20 / 61 / 482$ & HA & $0.4 / 1.7 / 4.6$ & $0.4 / 2.1 / 6.8$ & $\begin{array}{l}\text { Top soil / clayey material / Highly } \\
\text { weathered or fractured layer / Weathered } \\
\text { layer }\end{array}$ \\
\hline
\end{tabular}

Table 1.0: Summary of Geo-Electric 


\section{B. DISCUSSION OF RESULTS}

The VES data interpretation delineates three to four lithologic units. These are the topsoil, lateritic layer, weathered layer and fresh basement.

The results obtained from the quantitative interpretation of the sounding curves were used to generate the columnar section in Figure 5.

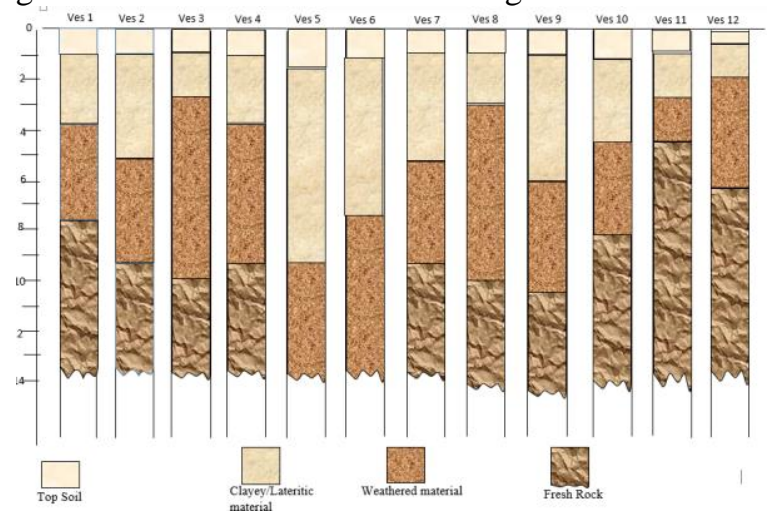

Figure 5.0: Shows the columnar sections of geoelectric parameters.

The columnar section show the geo- electric sequence of the various mapped layer with respect to depth. Also, it shows the vertical continuity of the geoelectric sequence across the VES stations along the traverses investigated. The parameters utilized in generating the sections are resistivity values and layer thicknesses. The columnar sections give an insight of the subsurface layering sequence in a 2 -dimensional form.

Groundwater potential was evaluated based on the thickness of the overburden, the thickness and the resistivity of the weathered layer

From Table 2, the overburden thickness ranges from 4.3 to $11.1 \mathrm{~m}$, and the probable depth to ground water levels are shown.

\begin{tabular}{|l|l|l|l|}
\hline $\begin{array}{l}\text { VES } \\
\text { Stati } \\
\text { on }\end{array}$ & $\begin{array}{l}\text { Overbur } \\
\text { den } \\
\text { thickness } \\
(\mathbf{m})\end{array}$ & $\begin{array}{l}\text { Depth to } \\
\text { Groundwate } \\
\mathbf{r ( m )}\end{array}$ & $\begin{array}{l}\text { Recommend } \\
\text { ation }\end{array}$ \\
\hline 1 & 7.7 & $40 \pm 5$ & $\begin{array}{l}\text { Medium } \\
\text { groundwater } \\
\text { Potential }\end{array}$ \\
\hline 2 & 11.1 & $45 \pm 5$ & $\begin{array}{l}\text { High } \\
\text { groundwater } \\
\text { Potential }\end{array}$ \\
\hline 3 & 10.2 & NIL & $\begin{array}{l}\text { Low } \\
\text { groundwater } \\
\text { Potential }\end{array}$ \\
\hline
\end{tabular}

\begin{tabular}{|l|l|l|l|}
\hline 4 & 9.1 & $35 \pm 5$ & $\begin{array}{l}\text { Medium } \\
\text { groundwater } \\
\text { Potential }\end{array}$ \\
\hline 5 & 9.1 & $40 \pm 5$ & $\begin{array}{l}\text { Medium } \\
\text { groundwater } \\
\text { Potential }\end{array}$ \\
\hline 6 & 7.4 & $30+5$ & $\begin{array}{l}\text { Medium } \\
\text { groundwater } \\
\text { Potential }\end{array}$ \\
\hline 7 & 9.7 & $40 \pm 5$ & $\begin{array}{l}\text { High } \\
\text { groundwater } \\
\text { Potential }\end{array}$ \\
\hline 8 & 10.0 & $30 \pm 5$ & $\begin{array}{l}\text { Medium } \\
\text { groundwater } \\
\text { Potential }\end{array}$ \\
\hline 9 & 10.9 & $40 \pm 5$ & $\begin{array}{l}\text { High } \\
\text { groundwater } \\
\text { Potential }\end{array}$ \\
\hline 10 & 8.3 & $40 \pm 5$ & $\begin{array}{l}\text { Medium } \\
\text { groundwater } \\
\text { Potential }\end{array}$ \\
\hline 11 & 4.3 & NIL & $\begin{array}{l}\text { Low } \\
\text { groundwater } \\
\text { Potential }\end{array}$ \\
\hline 12 & 6.8 & $40 \pm 5$ & $\begin{array}{l}\text { Medium } \\
\text { groundwater } \\
\text { Potential }\end{array}$ \\
\hline
\end{tabular}

VES stations 3 and 11 revealed low groundwater conditions. The weathered layers and overburden thicknesses are low and they are characterized with low degree of weathering and fracturing. VES stations $1,4,5,6,8,10$ and 12 shows a medium groundwater potential with considerable overburden thicknesses and weathered or fractured bedrock.

VES 2, 7 and 9 revealed a prolific aquifer potential as an indication of productive fracturing within the weathered basement and the very thick overburden which is most likely to store water (Table 2.). Groundwater extraction can be achieved by drilling to a depth of about $30 \mathrm{~m}$ to $45 \mathrm{~m}$ based on the interpretation of the acquired geophysical data.

\section{CONCLUSION}

Groundwater being the common source of water within the study area and its environs.

This research has provided information on the thickness of the overburden and depth to the groundwater aquifer unit in the study area. From the VES data interpretation, it has been confirmed that VES 2, 7 and 9 has a high groundwater potentials, VES $1,4,5,6,8,10$ has moderate groundwater potentials and VES 3 and 11 has a low groundwater potential. 


\section{International Journal of Engineering Applied Sciences and Technology, 2021 \\ Vol. 6, Issue 1, ISSN No. 2455-2143, Pages 88-93 \\ Published Online May 2021 in IJEAST (http://www.ijeast.com)}

Therefore, it is concluded that the study area has a good potential for groundwater exploitation.

\section{RECOMMENDATIONS}

Based on the result of this research work, it is recommended that constant geophysical research be conducted to ascertain the extent of the change in the engineering structure of the subsurface. It is advised that foundation to be placed on the site should be anchored on a pile to a depth of about 8-12m most especially if high rise building is to be placed there. Foundation with continuous footing is not advisable on soil alternating with stiffer soil.

\section{REFERENCE}

[1] Abubakar, Y. I and Auwal, L. Y., 2012. Geoelectrical Investigation of Groundwater Potential of Dawakin Tofa Local Government Area of Kano State Nigeria. American InternationalJournal of Contemporary Research 2(9): 188-1971 Reinhard Kirsch (2006) Groundwater

Geophysics - a Tool for Hydrogeology,

(Pg. 1).

[2] Adegoke O.S (1979) Thethyan affinities of West African Paleogene Molluscs. Proceedings, $24^{\text {th }}$ International Geological Congress, Montreal.

[3] Adepelumi, A. A., Akinmade, O. B and Fayemi, O., (2013). Evaluation of Groundwater Potential of Baikin Ondo State Nigeria Using Resistivity and Magnetic Techniques: A Case Study. Universal Journal of Geoscience 1(2): (pg37-45).

[4] Afolayan, J. F., Olorunfemi, M. O and Afolabi, O., (2004). Geoelectric/Electromagnetic VLF Survey for Groundwater in a Basement Terrain: A Case Study. Ife Journal of Science. 6(1):((pp74-78).

[5] Akande, W. G., Idris-Nda, A., Amadi, A. N., Abdulfatai, I. A., Alabi, A. A and Yahaya, T., (2016). Evaluation of groundwater potential of Chanchaga area, Minna, north-central Nigeria. American Journal of Innovative Research and Applied Science 2(1):( (Pg1-9).

[6] Bienibuor, A. K., Preko, K., Wemegah, D. D and Manu, E., (2016). The use of electromagnetic and electrical resistivity methods in assessing groundwater resource potentials in Adoe, Sunyani, Ghana. International Journal of Scientific and Technology Research 5(9) (Pp.166-170).

[7]Dan Hassan, M. A and Olurunfemi, M. O., (1999). Hydrogeophysical investigation of a Basement Terrain in the North Central part of Kaduna State
Nigeria" journal of mining and Geology 35(2) (pp189-206).

[8]J. A. Olatunji, o. V. Omonona and o. A. Odediran ,(2013)Electrical resistivity investigation of the groundwater potential in parts of Kwara state polytechnic, Ilorin, Nigeria. Global journal of pure and applied sciences vol. 23,: (pg157-166).

[9] Kumar, J. R. T., Dushiyanthan, C., Thiruneelakandan, B., Suresh, R., Vasanth Raja., S., Senthilkumar, $\mathrm{M}$ and Karthikeyan, K., (2016). Evaluation of Groundwater Potential Zones using Electrical Resistivity Response and Lineament Pattern in Uppodai Sub Basin, Tambaraparani River, Tirunelvel (pp 63-100)

[10] Oyawoye MO (1972) The basement complex of Nigeria. In: Dessauvagie TFJ, Whiteman AJ(eds) African geology. Ibadan University Press, (pp 66-102).

[11]Rahaman MA (1976). A Review of the Basement Geology of Southwestern

Nigeria.In Kogbe, C.A. (Editor), Publishing Co. (pp. 41-58)

[12] Telford, W.M., Geldart, L.P., Sheriff, R.E. and Keys, D.A. (1990). Applied geophysics. Cambridge University Press: Cambridge, UK. 